\title{
Rosanna Gorris Camos, "Le fleuve et le pré»: rhétorique du cœur et rhétorique de l'esprit chez Marguerite de Navarre
}

\section{Dario Cecchetti}

\section{(2) OpenEdition \\ Journals}

\section{Edizione digitale}

URL: http://journals.openedition.org/studifrancesi/7514

DOI: $10.4000 /$ studifrancesi.7514

ISSN: 2421-5856

\section{Editore}

Rosenberg \& Sellier

\section{Edizione cartacea}

Data di pubblicazione: 1 décembre 2009

Paginazione: 611

ISSN: 0039-2944

\section{Notizia bibliografica digitale}

Dario Cecchetti, «Rosanna Gorris Camos, «Le fleuve et le pré»: rhétorique du cœur et rhétorique de l'esprit chez Marguerite de Navarre», Studi Francesi [Online], 159 (LIII | III) | 2009, online dal 30 novembre 2015, consultato il 08 janvier 2021. URL: http://journals.openedition.org/studifrancesi/7514 ; DOI: https:// doi.org/10.4000/studifrancesi.7514

Questo documento è stato generato automaticamente il 8 janvier 2021.

\section{cc) $(9)$}

Studi Francesi è distribuita con Licenza Creative Commons Attribuzione - Non commerciale - Non opere derivate 4.0 Internazionale. 


\section{Rosanna Gorris Camos, «Le fleuve et le pré»: rhétorique du cœur et rhétorique de l'esprit chez Marguerite de Navarre}

Dario Cecchetti

\section{NOTIZIA}

ROSANNA GORRIS CAMOS, «Le fleuve et le pré»: rhétorique du coeur et rhétorique de l'esprit chez Marguerite de Navarre, in AA. VV., Rhétorique et littérature en Europe de la fin du Moyen Age au $\mathrm{XVII}^{\mathrm{e}}$ siècle, textes réunis et édités par Dominique de Courcelle, Turnhout, Brepols, 2008, pp. 63-86.

1 Il saggio di R. Gorris Camos rintraccia contatti e risonanze di vario genere fra l'opera di Marguerite de Navarre ed esponenti della riforma italiana, che alla principessa scrittrice si rivolgono sia facendola dedicataria di loro lavori sia presentandola come exemplum di clara mulier (interessanti e significative le annotazioni su Antonio Brucioli o su Giuseppe Betussi). In questo disegnare una mappa di rimandi concernenti spiritualità, erudizione e politica, l'A. ritrova in filigrana nell'Heptameron una rete di giochi retorici e di immaginario volti a costruire «una sorta di terapia di gruppo, di via Christi, per trovare la verità che si nasconde nel nostro cuore e che solo Cristo può rivelare». 